\title{
GENERASI Z DAN NILAI-NILAI YANG DIPERSEPSIKAN DARI ORANGTUANYA
}

\section{GENERATION Z AND THE PERCEIVED VALUES FROM THE PARENTS}

\author{
Muhammad Zulfa Alfaruqy \\ Fakultas Psikologi Universitas Diponegoro \\ zulfa.alfaruqy@gmail.com
}

\begin{abstract}
This study aimed to construct the values and process of socializing the values around adolescents in generation $Z$ which were obtained from their parents. This indigenous psychology research uses a grounded theory approach. 202 subjects categorized as teenagers from generation $Z$ and being college students were involved in this study. The results showed that the values perceived from their parents were personal values (42.92\%), interpersonal values (31.14\%), divine values (17.86\%), and political-cultural values (8.11\%). The aspects of nationality socialized by parents from the strongest to the weakest are respectively divinity, humanity, democracy, social justice, and nationalism. Generation $Z$ adolescents perceive that the process of socializing the values from parents is dominated by habituation of behavior that reflects certain values, followed by reminders of behavior, giving examples, involving two-way discussions, joint invitations to certain behaviors, involving one-way discussions, and giving rewards and punishments. The research has implications for policies that encourage the role of parents in the process of socializing noble values in the family.
\end{abstract}

Keywords: adolescents, generation Z, parents, socialization, values

\begin{abstract}
ABSTRAK
Tujuan penelitian adalah untuk mengkonstruksi nilai-nilai dan proses sosialisasi nilai remaja generasi $\mathrm{Z}$ yang dipersepsikan berasal dari orangtuanya. Penelitian indigenous psychology ini menggunakan pendekatan grounded theory. 202 subjek yang terkategorisasi sebagai remaja, generasi Z, dan berstatus mahasiswa dilibatkan dalam penelitian ini. Hasil penelitian menunjukkan bahwa nilai-nilai yang dipersepsikan berasal dari orangtuanya ialah nilai personal (42,92\%), nilai interpersonal $(31,14 \%)$, nilai ketuhanan $(17,86 \%)$, dan nilai politik-budaya $(8,11 \%)$. Nilai kebangsaan yang disosialisasikan oleh orangtua dari yang terkuat ke yang terlemah yaitu ketuhanan, kemanusiaan, demokrasi, keadilan sosial, dan nasionalisme. Remaja generasi Z mempersepsi bahwa proses sosialisasi nilai dari orangtua didominasi oleh pembiasaan perilaku yang mencerminkan nilai tertentu, yang diikuti dengan pengingatan kembali pada perilaku, pemberian keteladanan, pelibatan diskusi dua arah, ajakan bersama pada perilaku tertentu, pelibatan diskusi satu arah, serta pemberian reward dan punishment. Penelitian berimplikasi pada kebijakan yang mendorong peran orangtua dalam proses sosialisasi nilai-nilai mulia dalam keluarga.
\end{abstract}

Kata Kunci: generasi Z, nilai, orangtua, remaja, sosialisasi 


\section{PENDAHULUAN}

Generasi Z merupakan generasi yang lahir antara tahun 1995 hingga 2010. Sebagian di antara mereka memasuki fase perkembangan remaja dan dewasa awal (Santrock, 2018). Generasi Z tumbuh setelah menjamahnya internet (Pichler, 2021), di mana dunia digital yang maju begitu pesatnya (Gentina, 2020). Menurut Roberts dkk, (2014), remaja dari generasi Z menjadikan smartphone sebagai bagian dari kehidupan sehari-hari. Efeknya, remaja menginternalisasi nilai dalam hidup dari berbagai agen sosialisasi (Berns, 2013). Meskipun demikian, studi terkini tetap menempatkan orangtua pada posisi sentral dalam proses sosialisasi nilai (Barni dkk, 2020; Rico \& Jennings, 2015). Hal tersebut mendorong penelitian yang mengungkap nilai-nilai beserta proses sosialisasi yang dipersepsikan generasi Z dari orangtuanya.

Generasi merupakan kelompok individu yang mengalami konteks sejarah dan sosiokultural yang sama pada tahap perkembangan tertentu (Lyons \& Kuron, 2013). Genarasi Z ialah kategori kelompok dengan jumlah paling dominan dari berbagai kategorisasi generasi baik di Indonesia dengan 27,94\% populasi (BPS, 2020), maupun di berbagai belahan dunia (Spitznagel, 2020). Generasi Z dikenal sebagai generasi digital native yang telah mengenal teknologi seperti gawai sejak kecil (Roberts dkk, 2014). Generasi ini juga mampu mengekspresikan identitas mereka baik di lingkungan nyata maupun maya. Kemampuan dalam kolaborasi dan kreasi bersama ialah salah satu keunggulan adik dari generasi milenial (Gentina, 2020).

Remaja generasi Z menerima sosialisasi nilai dari berbagai pihak lantaran kecanggihan dunia digital. Secara singkat, sosialisasi dapat dimaknai sebagai proses di mana individu menyesuaikan diri dan menginternalisasi nilai, norma, kebiasaan dan perilaku dari kelompok sosial (Perez-Falkner, 2013). Menurut Berns (2013), nilai merupakan kualitas atau keyakinan yang dipandang sebagai sesuatu hal penting yang memandu perilaku dalam keseharian. Ada, setidaknya, sepuluh nilai yang berlaku secara universal yaitu tradisi, konformitas, keamanan, kebijakan, universalisme, kekuasaan, prestasi, hedonisme, stimuasi, dan pengarahan diri (Schwartz, 2012).

Penelitan Broadbent dkk (2017) menunjukkan bahwa nilai-nilai hidup generasi Z disosialisasikan dan dipengaruhi oleh orangtua (89\%), teman (78\%), guru (70\%), selebriti (30\%), dan politisi (17\%). Penelitian tersebut menegaskan urgensi keluarga, 
khususnya orangtua, dalam fungsi sosialisasi, di samping keempat fungsi yang lain lain yakni reproduksi, dukungan ekonomi, dukungan sosial, dan peran sosial (Lestari, 2016). Proses sosialisasi nilai orangtua - remaja terjadi dengan berbagai cara. Bao dkk (dalam Gentina, 2020) menyebut sosialisasi terjadi sacara unilateral dengan permintaan langsung dan persuasi; maupun bilateral dengan tawar-menawar dan penalaran. Selaras dengan Hatemi dan Ojeda (2020) yang menyebut sosialisasi dapat terjadi dengan transmisi langsung maupun proses dua arah.

Berdasarkan uraian di atas, maka muncul pertanyaan yaitu nilai-nilai apa saja yang dipersepsikan generasi $\mathrm{Z}$ berasal dari orangtuanya? Lalu, bagaimana proses sosialisasi nilai yang terjadi? Sehingga, tujuan penelitian adalah mengkonstruksi nilainilai dan proses sosialisasi nilai remaja generasi $\mathrm{Z}$ yang dipersepsikan berasal dari orangtuanya

\section{METODE PENELITIAN}

Penelitian indigenous psychology ini menggunakan pendekatan grounded theory. Indigenous psychology ialah paradigma dalam penelitian ilmu perilaku yang secara eksplisit memasukkan konteks sosial dalam memahami suatu fenomena (Kim dkk, 2006). Adapun grounded theory merupakan pendekatan dalam metode penelitian kualitatif yang berfokus untuk membangun kerangka konseptual atau teori melalui analisis induktif (Bryant \& Charmaz, 2019). Pendekatan ini diharapkan mampu membantu peneliti dalam mengkonstruksi nilai-nilai dan proses sosialisasi nilai remaja generasi $\mathrm{Z}$ yang dipersepsikan berasal dari orangtuanya.

Penelitian memiliki kriteria inklusi subjek yakni a) generasi Z yang memasuki tahap perkembangan remaja; b) berstatus sebagai mahasiswa; c) bersedia menjadi subjek penelitian. Peneliti mencari subjek penelitian pada bulan November 2021. Berdasarkan kriteria inklusi tersebut, maka diperoleh 202 subjek. Peneliti memberikan kuesioner daring yang terdiri dari informed consent, isian identitas subjek, dan pertanyaan. Informed consent diberikan sebagai bentuk kesediaan secara sadar terlibat dalam penelitian, Adapun identitas subjek dibutuhkan untuk cross-check kriteria inklusi. Pertanyaan open-ended digunakan dalam pengumpulan data. Pertanyaan dalam penelitian ini meliputi: a) Ungkaplah nilai-nilai hidup yang Anda peroleh dari orangtua! 
b) Seberapa kuat nilai kebangsaan Anda peroleh dari orangtua? c) Bagaimana cara orangtua melakukan sosialisasi nilai-nilai?

Teknik analisis data menggunakan grounded theory yang dikembangkan oleh Corbin dan Strauss (dalam Bryant \& Charmaz, 2019) (lihat gambar 1). Pertama, open coding yaitu langkah memecah data menjadi bagian-bagian terpisah, memberikan label dengan kode konseptual, serta mengelompokkan ke dalam kategori-kategori konsep. Kedua, axial coding yaitu langkah mengumpulkan kategori yang mirip telah diperoleh pada tahap open coding. Ketiga, selective coding yaitu langkah menghubungkan kategori bersandarkan pada saling keterkaitan.

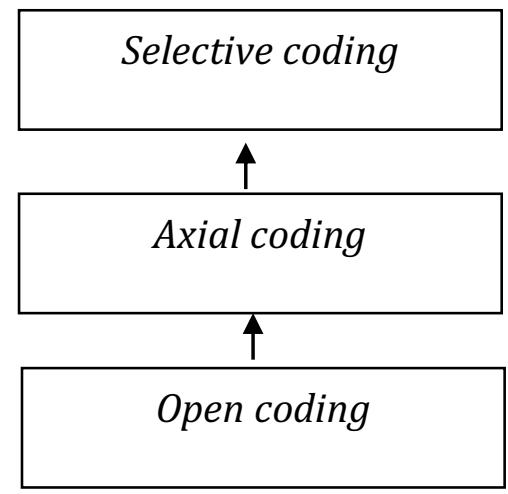

Gambar 1. Analisis data

\section{HASIL PENELITIAN}

\section{Nilai-Nilai yang Dipersepsikan}

Penelitian memberi keleluasaan bagi subjek untuk mengungkap nilai-nilai hidup yang diperoleh dari orangtua. Setiap subjek dapat menjawab lebih dari satu nilai. 851 respon muncul dari 202 subjek. Hasil analisis menemukan bahwa nilai-nilai yang dipersepsikan berasal dari orangtuanya terdiri dari 4 kategori yaitu nilai personal, nilai interpersonal, nilai ketuhanan, dan nilai politik-budaya (lihat Tabel 1). Pertama, nilai yang paling dominan yaitu nilai personal $(42,92 \%)$. Remaja generasi Z menyebut tujuh nilai yang terkait dengan kapasitas personal yaitu tanggung jawab, disiplin, mandiri, syukur, kerja keras, manajemen diri, dan jujur.

Kedua, nilai interpersonal $(31,14 \%)$, yang mencerminkan bagaimana remaja generasi Z harus berelasi dengan orang lain. Setidaknya ada lima nilai interpersonal yang utama yaitu hormat, sopan santun, tolong-menolong, keberanian bersosialisasi, dan kekeluargaan. Ketiga, nilai ketuhanan (17,86\%), yang mencerminkan bagaimana remaja 
generasi $\mathrm{Z}$ harus berelasi dengan Tuhannya. Ada dua nilai yang menjadi sorotan yaitu nilai agama dan ritual praktik ibadah. Keempat, atau yang terakhir, adalah nilai politikbudaya $(8,11 \%)$ yang meliputi nilai politik dan nilai kebudayaan itu sendiri.

Tabel 1. Nilai-nilai yang Dipersepsikan dari Orangtua

\begin{tabular}{|c|c|c|c|}
\hline No & Nilai-nilai & & $\mathbf{n}$ \\
\hline \multirow[t]{8}{*}{1} & Personal & & 354 \\
\hline & a. Tanggung jawab & 64 & $(42,89 \%)$ \\
\hline & b. Disiplin & 64 & \\
\hline & c. Mandiri & 51 & \\
\hline & d. Syukur & 45 & \\
\hline & e. Kerja keras & 44 & \\
\hline & f. Manajemen diri & 35 & \\
\hline & g. Jujur & 21 & \\
\hline \multirow[t]{6}{*}{2} & Interpersonal & & 265 \\
\hline & a. Hormat & 65 & $(31,14 \%)$ \\
\hline & b. Sopan santun & 64 & \\
\hline & c. Tolong-menolong & 62 & \\
\hline & d. Sosial & 41 & \\
\hline & e. Kekeluargaan & 33 & \\
\hline \multirow[t]{3}{*}{3} & Ketuhanan & & 152 \\
\hline & a. Agama & 123 & $(17,86 \%)$ \\
\hline & b. Praktik ibadah & 29 & \\
\hline \multirow[t]{3}{*}{4} & Budaya dan Politik & & 69 \\
\hline & a. Budaya & 57 & $(8,11 \%)$ \\
\hline & b. Politik & 12 & \\
\hline & Total & & $851(100 \%)$ \\
\hline
\end{tabular}

\section{Kebangsaan}

Penelitian juga menemukan seberapat kuat nilai kebangsaan yang diperoleh remaja generasi $Z$ dari orangtua (lihat Gambar 2). Setiap nilai terdiri dari 2 aitem dengan nilai tertinggi 4, sehingga nilai total maksimalnya adalah 8,00. Pertama, nilai kebangsaan yang paling kuat adalah sila pertama (ketuhanan) sebesar 7,60. Remaja diajarkan oleh orangtua untuk mempercayai Tuhan Yang Maha Esa, menjalankan perintah-Nya, serta tidak memaksakan kepercayaan agama yang dipercayai kepada orang lain.

Kedua, nilai kebangsaan sila kedua (kemanusiaan) sebesar 7,46. Remaja diajarkan oleh orangtua untuk mengakui persamaan hak dan kewajiban antar sesama manusia, sekaligus menebarkan kasih sayang. Ketiga, nilai kebangsaan sila keempat (demokrasi) 
sebesar 7,14. Remaja diajarkan oleh orangtua untuk mengambil keputusan berdasarkan musyawarah mufakat, serta aktif bertanggung jawab menjalankan keputusan yang telah diambil.

Keempat, nilai kebangsaan sila kelima (keadilan sosial) sebesar 7,02. Remaja diajarkan oleh orangtua untuk menyeimbangkan keadilan hak dan kewajiban dalam masyarakat, serta mengembangkan potensi diri untuk khalayak luas. Kelima, atau yang terlemah, adalah nilai kebangsaan sila ketiga (nasionalisme). Remaja diajarkan oleh orangtua untuk mengutamakan kepentingan negara-bangsa daripada diri sendiri maupun kelompok serta mengembangkan rasa persatuan antar sesama anak bangsa. Singkat kata, nilai kebangsaan yang diajarkan oleh orangtua dari yang terkuat ke yang terlemah yaitu ketuhanan, kemanusiaan, demokrasi, keadilan sosial, dan nasionalisme.

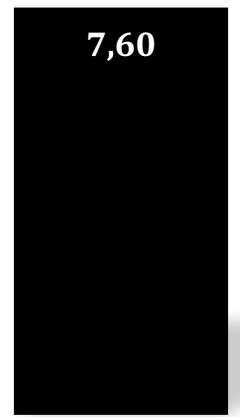

1

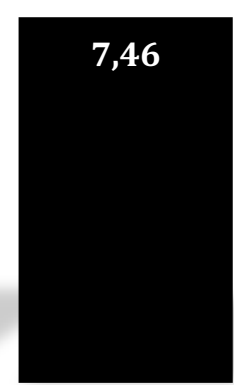

2

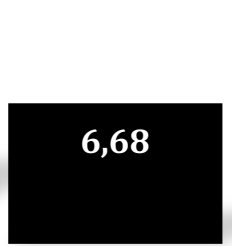

3

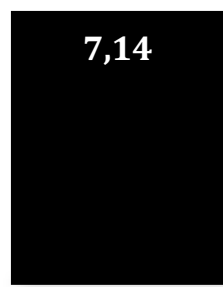

4

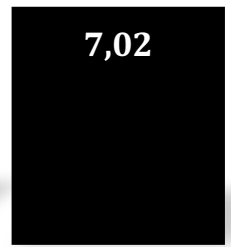

5

Gambar 2. Nilai Kebangsaan dari Orangtua

\section{Proses Sosialisasi}

Sosialisasi nilai mencerminkan multiproses. Pertama, pembiasaan manifestasi perilaku (81,19\% subjek). Subjek melaporkan bahwa proses sosialisasi yang paling dominan adalah pembiasaan atau kondisioning nilai yang termanifestasi pada perilaku. Sebagaimana disampaikan oleh Subjek dengan kode 136 atau S136. Subjek S136 menyampaikan bahwa dirinya dibiasakan sejak kecil untuk senantiasa mengucapkan tolong, maaf, dan terima kasih ketika berinteraksi dengan orang lain. Subjek S167 mengungkapkan bahwa sebagai anak pertama, dirinya dibiasakan untuk bertanggungjawab tidak hanya pada dirinya namun juga terkait dengan adik-adiknya. 
"Orang tua saya selalu membiasakan saya untuk mengucapkan tiga kata kunci ketika berinteraksi dengan orang lain: tolong, maaf, dan terima kasih kepada siapapun itu" (S136)

"Saya merupakan anak pertama dari 5 bersaudara. karena status ini, saya selalu dibiasakan untuk menjadi kakakyang bertanggungjawab buat adik-adiknya, berani untuk melindungi mereka, dan menjadi contoh bagi adik-adik saya dalam nilai-nilai yang sudah ditanamkan oleh orang tua." (S167)

Kedua, peringatan pada konsistensi perilaku (70,30\% subjek). Subjek menuturkan bahwa orangtua juga mengingatkan kepadanya untuk konsisten dengan perilaku yang mencerminkan nilai tertentu. Subjek S100 menyampaikan bahwa orangtua, khususnya ibu, senantiasa mengingatkannya untuk rendah hati dan sopan ketika berinteraksi dengan orang lain, meskipun hati sedang kesal. Subjek S202 mengungkap bahwa orangtuanya mengingatkan dirinya dalam hal kedisiplinan waktu. Misalnya tepat waktu saat pengerjaan tugas.

"Ibu saya biasa mengingatakan saya untuk tetap sopan dan rendah hati disaat saya sedang kesal dengan orang lain" (S100)

"Orangtua saya selalu mengingatkan saya untuk mengerjakan setiap tugas saya secara tepat waktu' (S202)

Ketiga, pemberian keteladanan $(65,35 \%$ subjek $)$. Keteladanan orangtua merupakan alternatif yang lazim dilakukan orangtua dalam sosialisasi nilai. Misalnya, orangtua subjek S094 yang memberi contoh dalam mendirikan sholat dan mengaji AlQuran, serta mengajak ke panti asuhan. Orangtua subjek S179 mencontohkan dalam hal kerapian kamar dan rumah. Hal-hal yang dilakukan orangtua dalam kehidupan seharihari ini merupakan modelling bagi anak-anak remajanya.

"Orang tua saya memberikan keteladanan dalam menanamkan nilai agama dengan rajin sholat berjamaah dan mengaji, mengerjakan sholat sunnah, mengajak ke panti asuhan dsb" (S094)

"Orangtua mencontohkan dengan kerapian kamar orangtua saya dan kondisi rumah." (S179)

Keempat, pemahaman dua arah (61,88\% subjek). Sebagian subjek remaja generasi $\mathrm{Z}$ juga mengungkapkan pemahaman dua arah berupa diskusi dalam proses sosialisasi niali. Subjek S130 mengatakan bahwa orangtuanya telah menanamkan nilainilai yang dipersepsikan penting untuk diinternalisasikan kepada anak melalui aktivitas mengobrol santai. Sementara subjek S142 juga mengatakan bahawa orangtuanya tidak 
memaksakan kehendak, namun memilih untuk diskusi bersama sebelum memutuskan urgensi sebuah nilai.

"Ibu selalu menerapkan komunikasi dua arah. Contohnya ketika mengobrol santai, ibu akan selalu menyisipkan nilai nilai yang diajarkan." (S130)

"Orang tua saya tidak pernah memaksakan kehendak saya sebagai anak ataupun sebagai manusia. Orang tua saya selalu mengajak saya untuk diskusi terlebih dahulu sebelum melakukan atau memutuskan hal yang saya perlu lakukan." (S142)

Kelima, ajakan pada manifestasi perilaku (58,42\% subjek). Sebagian orangtua aktif melakukan ajakan kepada subjek remaja pada sebuah aktivitas bersama yang merupakan manifestasi nilai dalam perilaku. Misalnya subjek S050 yang menuturkan bahwa orangtua, khususnya ibu, menanamkan nilai agama dengan mengajak subjek untuk bangun malam guna mendirikan sholat tahajud. Ajakan bersama untuk sholat tahajud membawa perubahan perilaku bagi subjek. Subjek menjadi terbiasa untuk sholat tahajud. Demikian halnya dengan ajakan puasa sunnah.

"Ibu saya mengajak saya bangun malam terus dan menyetel alarm di sekitar jam 2 malam untuk melakukan sholat tahajud. Sekarang, saya mulai sedikit rajin untuk sholat malam. Selain itu, ibu saya juga mengajarkan untuk puasa sunah. Beliau selalu mengajak saya untuk berpuasa bersama." (S050)

Keenam, pemahaman satu arah (50,99\% subjek). Sebagaian subjek menyatakan bahwa sosialisasi nilai orangtua-anak remaja dilakukan dengan pemahaman satu arah. Pemahaman satu arah menempatkan orangtua sebagai pihak yang dominan, misalnya berwujud pemberian nasihat. Subjek S004 menuturkan bahwa orangtuanya memberi nasihat tentang kejujuran. Kejujuran merupakan landasan dalam setiap aktivitas, meskipun tidak selalu menyenangkan atau pahit. Subjek S075 terkesan dengan cara orangtuanya memberikan nasihat tentang agama. Misalnya nasihat terkait dengan kedisiplinan ibadah dan doa kepada Tuhan Yang Maha Esa. Selain itu, terdapat pula nasihat tentang tata cara berpakaian yang rapi dan menutup aurat.

"Memberi nasihat mengenai apapun harus didasari atas prinsip kejujuran walaupun pahit sekalipun" (S004)

"Memberi saya nasehat tentang agama, seperti cara berpakaian yang rapih dan menutup aurat, menyuruh saya untuk selalu rajin beribadah dan berdoa minta apapun ke Tuhan," (SO75) 
Ketujuh, atau yang terakhir, adalah pemberian umpan balik (27,72\% subjek). Sebagian subjek menyampaikan bahwa orangtuanya menanamkan nilai dengan pemberian umpan balik. Umpan balik yang dimaksud ialah berupa reward (hadiah) dan punishment (hukuman). Sebagaimanq dijelaskan oleh S015 yang mendapatkan reward terkait kerja keras dalam pendidikan.

"Ketika saya melakukan apa yang saya pilih dan saya berhasil, misalnya saya lulus dengan nilai yang baik saya akan di kasih reward, namun ketika saya memilih suatu hal namun saya langgar dari ketentuannya saya dikasih peringatan" (S015)

\section{DISKUSI}

Interaksi orangtua-remaja generasi $\mathrm{Z}$ memainkan peran penting dalam rangka sosialisasi nilai. Penelitian ini menemukan nilai-nilai yang dipersepsikan berasal dari orangtuanya ialah nilai personal $(42,92 \%)$ berupa tanggung jawab, disiplin, mandiri, syukur, kerja keras, manajemen diri, dan jujur; nilai interpersonal $(31,14 \%)$ berupa hormat, sopan santun, tolong-menolong, keberanian bersosialisasi, dan kekeluargaan; nilai ketuhanan $(17,86 \%)$ berupa agama dan ritual praktik ibadah; serta nilai politikbudaya (8,11\%). Penelitian Sihombing (2014) menyebutkan bahwa gotong-royong, agama, demokrasi, kekeluargaan, dan keramahan adalah katergori nilai positif pemuda di Indonesia saat ini, Penelitian tersebut juga menemukan adanya nilai negatif yaitu korupsi, budaya barat, fanatisme agama, dan egoisme.

Ketagori nilai personal, interpersonal, ketuhanan, dan politik-budaya menjadi alternatif klasik kategorisasi nilai yang telah ditawarkan Schwartz (2012). Pada populasi umum Schwartz (2012) mengkategorisasi nilai yaitu self oriented values dan other oriented values. Self oriented values terdiri dari prestasi, kekuasaan, hedonisme, stimulasi, dan pengarahan diri. Sementara other oriented values terdiri dari kebajikan, konformitas, universalisme, keamanan, dan tradisi. Selaras dengan Gentina (2020) yang mengusulkan socio-orientation dan concept-orientation.

Penelitian ini juga telah mengungkap nilai kebangsaan yang disosialisasikan oleh orangtua dari yang terkuat ke yang terlemah yaitu ketuhanan, kemanusiaan, demokrasi, keadilan sosial, dan nasionalisme. Temuan penelitian ini melengkapi penelitianpenelitian sebelum tentang nilai-nilai Pancasila dari perspektif hukum (Hesyansyah, 
2014), pemerintahan (Widiyaningrum, 2019), maupun psikologi (Meinarno dkk, dalam Hafiz \& Meinarno, 2019). Kondisi kebangsaan menuntut nasionalisme dan peran generasi muda (Alfaruqy, 2019). Sementara, nasionalisme generasi muda tidak dapat lepas dari orang-orang signifikan dalam hidupnya, termasuk orang tua (Alfaruqy \& Masykur, 2014)

Penelitian menunjukkan bahwa remaja generasi $\mathrm{Z}$ mempersepsi bahwa proses sosialisasi nilai dari orangtua didominasi oleh pembiasaan perilaku yang mencerminkan nilai tertentu, yang diikuti dengan pengingatan kembali pada perilaku, pemberian keteladanan, pelibatan diskusi dua arah, ajakan bersama pada perilaku tertentu, pelibatan diskusi satu arah, serta pemberian reward dan punishment. Proses tersebut merupakan kombinasi antara strategi unilateral dan bilateral (Gentina, 2020). Penelitian berimplikasi pada kebijakan yang mendorong peran orangtua dalam proses sosialisasi nilai-nilai mulia dalam keluarga. Peran keluarga urgen hadir bagi tumbuh kembang generasi $\mathrm{Z}$ yang memiliki konektivitas tinggi terhadap gawai (Gentina, 2020). Orantua perlu mengembangkan diri, khususnya dalam penggunaan teknologi, guna mengontrol dan memanfaatkannya sebagai media penanaman nilai.

\section{KESIMPULAN DAN SARAN}

Nilai-nilai yang dipersepsikan remaja generasi Z yang berasal dari orangtuanya ialah nilai personal $(42,92 \%)$, nilai interpersonal $(31,14 \%)$, nilai ketuhanan $(17,86 \%)$, dan nilai politik-budaya $(8,11 \%)$. Nilai kebangsaan yang disosialisasikan oleh orangtua dari yang terkuat ke yang terlemah yaitu ketuhanan, kemanusiaan, demokrasi, keadilan sosial, dan nasionalisme. Remaja generasi Z mempersepsi bahwa proses sosialisasi nilai dari orangtua didominasi oleh pembiasaan perilaku yang mencerminkan nilai tertentu, yang diikuti dengan pengingatan kembali pada perilaku, pemberian keteladanan, pelibatan diskusi dua arah, ajakan bersama pada perilaku tertentu, pelibatan diskusi satu arah, serta pemberian reward dan punishment. Penelitian berimplikasi pada kebijakan yang mendorong peran orangtua dalam proses sosialisasi nilai-nilai mulia dalam keluarga

\section{DAFTAR PUSTAKA}


Alfaruqy, M.Z. (2019). Perilaku politik generasi milenial: Sebuah studi perilaku memilih (voting behavior). Jurnal Psikologi Jambi, 4(1), 10-15.

Alfaruqy, M.Z. \& Masykur, A. M. (2014). Memaknai nasionalisme. Jurnal Empati, 3(2), 246256.

Berns, R. M. (2013). Child, family, school, community socialization and support (9th ed.). Belmont, CA: Wadsworth.

Barni, D., Russo, C., Zagrean, I., Fabio, M.D., \& Danioni, F. (2020). Adolescents' internalization of moral values: the role of paternal and maternal promotion of volitional functioning. Journal of Family Studies, 1-13.

Broadbent, E., Gougoulis, J., Lui, N., Pota, V., \& Simons, J. (2017). Generation Z: Global citizenship survey. London: Varkey Foundation

Bryant, A. \& Charmaz, K. (2019). The sage handbook of current development in grounded theory. London: Sage Publication.

BPS. (2020). Hasil sensus penduduk 2020. Berita Resmi Statistik, 7(1), 1-12.

Gentina, E. (2020). Generation Z in Asia: a research agenda. In E. Gentina \& E. Parry (eds). The new generation $Z$ in Asia: Dynamics, differences, digitalization (The changing context of managing people (pp 3-19). Bingley: Emerald Publishing.

Heryansyah, D. (2014). Tanggung jawab pemuda terhadap masa depan Pancasila. Jurnal Hukum Ius Quia Iustum, 21(4), 607-631.

Kim, U., Yang, K., \& Hwang, K. (2006). Indigenous and cultural psychology: Understanding people in context. New York, NY: Springer.

Lestari, S. (2016). Psikologi keluarga: Penanaman nilai \& penanganan konflik dalam keluarga. Jakarta: Kencana.

Lyons, S., \& Kuron, L. (2013). Generational differences in the workplace: A review of the evidence and directions for future research. Journal of Organizational Behavior, 35(S1), S139-S157.

Meinarno, E.A., Putri, M.A., \& Fairuziana. (2019). Isu-isu kebangsaan dalam ranah psikologi Indonesia. Dalam S.E. Hafiz \& E.A. Meinarno (Eds). Psikologi Indonesia (pp 59-84). Depok: Rajawali Pers.

Perez-Felkner, L. (2013). Socialization in children and adolescence. Dalam J. Delamater \& A. Ward (Eds.). Handbook of social psychology (2nd ed.) (pp 119-151). London: Springer.

Pichler, S., Kohli, C., \& Granitz, N. (2021). DITTO for Gen Z: A framework for leveraging the uniqueness of the new generation. Business Horizons, 64(5), 599-610.

Rico, G. \& Jennings, M.K. (2015). The information of left-right identification: Pathways and correlates of parental influence. Political Psychology, 0(00), 1-16.

Roberts, J., Yaya, L., \& Manolis, C. (2014). The invisible addiction: Cell-phone activities and addiction among male and female college students. Journal of Behavioral Addictions, 3(4), 254-265.

Santrock, J.W. (2018). Life-span development (17th ed.). New York, NY: McGraw Hill Education.

Schwartz, S.H. (2012). Values and religion in adolescent development: Cross-national and comparative evidence. In G. Trommsdorff \& X. Chen (Eds). Values, religion, and culture in adolescent development (pp.97-122). Cambridge: Cambridge University Press. 
Sihombing, S. O. (2014). Identifying current values of Indonesian youth. Dalam International conference on business and management research: International market integration. Kyoto: Kyoto University.

Spitznagel, E. (2020). Generation Z is bigger than millennials - and they're out to change the world. New York Post. https://nypost.com/2020/01/25/generation-z-is-biggerthan-millennials-and-theyre-out-to-change-the-world/

Tamm, A. \& Tulviste, T. (2020). To what extent do perceived parental socialization values match Estonian adolescents' personal values? Child Indicators Research, 13, 18111825.

Widiyaningrum, W. Y. (2019). Menumbuhkan nilai kesadaran Pancasila di kalangan generasi muda: Kajian teoretis. Jurnal JISIPOL, 3(3), 69-58. 